\title{
STRUKTUR KEPEMILIKAN, CORPORATE GOVERNANCE, AGENCY COST, DAN KINERJA PERUSAHAAN
}

\author{
Tyara Dwi Putri \\ Jurusan Manajemen, Fakultas Ekonomi dan Bisnis, Universitas Bung Hatta \\ tyaradwiputri@bunghatta.ac.id
}

\begin{abstract}
Absract: This studyaims to anlyze effect of ownership structure, capital structure, corporate governance and agency cost on firm performance. The sample used is 20 family companies listed on the Indonesia Stock Exchange period 2016-2018. Ownership Structure is determined by family ownership. Corporate governance measured by number of director and percentage of independent commissioners. Proxy of agency cost is asset utilization and expense ratio. Firm performance measured by Return on Equity (ROE). The results showed that family ownership and number of directors has no effect on company performance. Meanwhile, independent commissioners, asset utilization and expense ratio have an effect on company performance.
\end{abstract}

Keywords: Ownership Structure, Corporate Governance, Agency Cost, Firm Performance

\begin{abstract}
Abstrak: Penelitian ini bertujuan untuk menganalisis pengaruh struktur kepemilikan, corporate governance, agency cost, terhadap kinerja perusahaan. Sampel yang digunakan adalah sebanyak 20 perusahaan keluarga yang terdaftar di Bursa Efek Indonesia periode 2016-2018. Struktur kepemilikan diukur dengan kepemilikan saham oleh pihak keluarga. Corporate governance diukur dengan jumlah dewan direksi dan persentase komisaris independen. Proksi untuk agency cost adalah asset utilization dan expense ratio. Kinerja perusahaan diukur dengan Return on Equity (ROE). Hasil penelitian menunjukkan bahwa kepemilikan keluarga dan direksi tidak berpengaruh terhadap kinerja perusahaan. Sedangkan, komisaris independen, asset utilization dan expense ratio berpengaruh terhadap kinerja perusahaan.
\end{abstract}

Kata Kunci: Struktur Kepemilikan, Corporate Governance, Agency Cost, dan Kinerja Perusahaan.

\section{A. PENDAHULUAN}

Kinerja keuangan perusahaan dapat tergambar dari laporan keuangan yang dikeluarkan perusahaan. Kinerja perusahaan merupakan ukuran untuk keberhasilan suatu perusahaan dalam melaksanakan fungsi-fungsi keuangannya. Kinerja keuangan perusahaan tidak dapat ditingkatkan apabila adanya konflik yang terjadi diadalam perusahan. Konflik tersebut adalah konflik kepentingan yang terjadi antara pihak agent dan principal yang sering disebut dengan konflik keagenan (agency conflict) (Brigham dan Ehrhardt, 2011). Masalah keagenan juga bisa terjadi karena asymetric information antara manajer dan pemegang saham, yaitu ketika salah satu pihak memiliki informasi yang tidak dimiliki oleh pihak lain. Biasanya seorang manajer akan mempunyai informasi yang lebih dari pada investor perusahaan. (Brigham dan Ehrhardt, 2011).

Adanya pemisahan antara fungsi kepemilikan (ownership) dan fungsi pengendalian (control) juga dapat menimbulkan masalah keagenan (agency conflict) (Jensen dan Meckling, 1976). Dengan adanya konfilk tersebut agent dan principal akan menuntut adanya suatu kebijakan yang dapat mensejajarkan kepentingan mereka. Hal 
ini tentunya akan dapat menimbulkan biaya keagenan (agency cost). Biaya keagenan ini merupakan indikator terjadinya masalah keagenan, baik kaitannya dengan biaya pemantauan (monitoring cost) oleh prinsipal, biaya perikatan (bonding cost) oleh agen, maupun kerugian residual (residual cost) sebagai pengurang kekayaan prinsipal (Jensen dan Meckling, 1976).

Karena kepemilikan mewakili suatu sumber kekuasaan (source of power) yang dapat digunakan untuk mendukung atau sebaliknya terhadap keberadaan manajemen, maka konsentrasi atau penyebaran power menjadi suatu hal yang relevan. Dengan adanya konsentrasi kepemilikan, pemegang saham dapat mengawasi manajer dengan lebih baik (Shleifer dan Vishny, 1986). Manajer sebagai pemilik perusahaan akan bertindak demi kepentingan perusahaan (Jensen dan Meckilng, 1976). Astuti, dkk (2015) menemukan bahwa kepmilikan keluarga berpengaruh signifikan terhadap kinerja perusahaan, keluarga sebagai pemilik perusahaan memilikikontrol manajemen dalam melakukan pengawasan.

Corporate governace merupakan cara yang dilakukan oleh perusahaan untuk dapat menjalankan perusahaannya. Struktur dari tata kelola perusahaan yang baik (good corporate governace) dapat menentukan sukses atau tidaknya suatu perusahaan. Porter (1991) menjelaskan alasan mengapa perusahaan sukses atau gagal disebabkan oleh strategi yang diterapkan perusahaan tersebut. Kesuksesan suatu perusahaan banyak ditentukan oleh karakteristik strategis perusahaan yang mencakup strategi penerapan sistem good corporate governace. Lemmons dan Lins (2003), Brown dan Caylor (2004), dan Black et al (2006), Faleye (2007), dan Baghat dan Bolton (2008) menyatakan bahwa corporate governace berpengaruh positif dan signifikan terhadap kinerja perusahaan, banyak proksi yang digunakan untuk memproksikan corporate governace tersebut.

\section{B. TINJAUAN PUSTAKA}

\section{Agency Theory}

Teori keagenan membahas hubungan antara agent dan principal. Dimana agent adalah manajemen pengelola perusahaan sedangkan principal adalah pemegang saham. Agent dan principal tersebut diikat oleh suatu kontrak yang menyatakan hak dan kewajiban masing-masing. Principal memberikan fasilitas dan dana untuk menjalankan perusahaan. Teori keagenan ini timbul karena adanya asymmetric information antara prinsipal dan agen, assymetric interest antara prinsipal dan agen serta karena adanya unobservable behavior atau bounded rationality. Dengan adanya ketiga hal tersebut maka antara prinsipal dan agen akan mengutamakan kesejahteraan masing-masing. Agen akan berusaha memaksimalkan kemakmurannya dengan mengharapkan kompensasi yang besar. Sedangkan pemegang saham akan memaksimalkan kesejahteraan melalui pembagian dividen yang maksimal.

\section{Agency Cost}

Jensen dan Meckling (1976) agency cost merupakan biaya yang muncul ketika kepentingan manajer perusahaan atau agent tidak sesuai dengan kepentingan pemilik perusahaan atau principal dan akan mempengaruhi pilihan dalam tugas, kelalaian, dan keputusan manajer berdasarkan kepentingan sendiri maupun entrenchment yang akan mengurangi kesejahteraan principal. Jensen dan Meckling (1976) mengatakan bahwa biaya keagenan terdiri dari :Biaya pemantauan (monitoring cost) merupakan biaya yang dikeluarkan untuk mengawasi perilaku agen, termasuk usaha untuk membatasi anggaran dan kebijakan investasi. Bounding cost merupakan biaya yang dikeluarkan oleh para 
agen untuk menjamin dirinya tidak akan melakukan tindakan tertentu yang merugikan prinsipal atau digunakan untuk menjamin bahwa prinsipal akan diberi kompensasi jika para agen tidak mengambil banyak tindakan.Residual loss merupakan penurunan tingkat kesejahteraan prinsipal maupun agen setelah adanya hubungan keagenan.

\section{Corporate Governance}

Menurut Lukviarman (2004) para ahli sepakat menyatakan bahwa sistem corporate governance yang dianut Indonesia mengikuti pola Continental European system dengan ciri-ciri dianutnya sistem dan perangkat hukum yang bersumber pada tradisi French-Civil Law, digunakannya dua struktur dewan perusahaan (two-tier board system), terkonsentrasinya kepemilikan perusahaan (concentrated ownership structure), dan dominannya sumber pembiayaan perusahaan dari luar perusahaan berupa hutang (external financing).

\section{Penelitian Terdahulu dan Pengembangan Hipotesis \\ Pengaruh Struktur Kepemilikan terhadap Kinerja Perusahaan}

Struktur kepemilikan perusahaan adalah penentu utama dari tingkat agency problem antara insider dan investor luar, yang memiliki implikasi penting untuk penilaian perusahaan. Shleifer dan Vishny (1986) menyatakan bahwa kehadiran pemegang saham besar memiliki arti penting dalam memonitor manajer. Struktur kepemilikan yang dimiliki oleh pihak keluarga dianggap lebih efisien dari pada kepemilikan non keluarga dikarenakan biaya pengawasan yang harusnya dikeluarkan akan lebih kecil. Astuti, dkk (2015) dan Indarwati (2015) menemukan bahwa kepemilikan keluarga berpengaruh signifikan terhadap kinerja perusahaan.

Berdasarkan hasil penelitian terdahulu tersebut, maka dirumuskan hipotesis sebagai berikut:

$\mathrm{H}_{1}$ : Kepemilikan keluarga berpengaruh positif terhadap kinerja perusahaan.

\section{Pengaruh Corporate Governance terhadap Kinerja Perusahaan}

Corporate governance merupakan serangkaian peran yang dapat melindungi pihak-pihak minoritas dalam perusahaan dari eksproriasi yang dilakukan oleh manajer dan pemegang saham pengendali atau mayoritas dalam perusahaan (Shleifer dan Vishny, 1997). Corporate governance yang baik dalam sebuah perusahaan diduga dapat meningkatkan kinerja perusahaan. Keberhasilan penegakan good corporate governance sangat ditentukan oleh kualitas pengurusnya yaitu komisaris sebagai pengawas dan direksi sebagai pelaksana.

Nam dan Nam (2004), menjelaskan bahwa dewan direksi dan komisaris independen merupakan peran corporate governance yang sangat penting dalam perusahaan. Komisaris independen dalam perusahaan adalah komisaris yang bukan merupakan karyawan perusahaan tersebut, bukan merupakan kerabat atau keluarga, bukan pemegang saham mayoritas, dan tidak memiliki kepentingan / minat bisnis yang serius dalam perusahaan. Darwis (2009), Prasinta (2012), dan Muchtar dan Darari (2013) menemukan bahwa corporate governance berpengaruh positif terhadap kinerja perusahaan.

Berdasarkan hasil penelitian terdahulu tersebut, maka dirumuskan hipotesis sebagai berikut:

$\mathrm{H}_{2 \mathrm{a}}$ : Dewan direksi berpengaruh positif terhadap kinerja perusahaan. 
$\mathrm{H}_{2 \mathrm{~b}}$ : Komisaris Independen berpengaruh positif terhadap kinerja perusahaan.

\section{Pengaruh Agency Cost terhadap Kinerja Perusahaan}

Agency cost dapat diminimalisir dengan adanya kontrol dari pihak shareholder, serta dengan adanya sistem corporate governance yang baik maka kemungkinan terjadinya konflik dalam perusahaan akan semakin kecil (Saltaji, 2013; Rashid, 2015). Ang et al. (2000) menggunakan asset utilization ratio dan expense ratio sebagai pengukuran agency cost. Asset utilization ratio digunakan untuk mengukur efisiensi penggunaan aktiva oleh manajemen. Semakin tinggi rasio ini maka akan semakin tinggi produktif aktiva untuk meningkatkan nilai bagi pemegang saham. Kemudian expense ratio digunakan untuk mengukur biaya keagenan berdasarkan rasio beban operasi terhadap total penjualannya. Rasio ini memberikan menjelaskan diskresi manajerial dalam membelanjakan sumber daya yang ada. Semakin tinggi rasio ini menjelaskan bahwa biaya keagenan perusahaan semakin tinggi.

Layyinaturrobaniyah, dkk (2014) menemukan bahwa expense ratio berpengaruh negatif terhadap kinerja perusahaan, dan asset utilization berpengaruh positif terhadap kinerja perusahaan.

Berdasarkan hasil penelitian terdahulu tersebut, maka dirumuskan hipotesis sebagai berikut:

$\mathrm{H}_{3 a} \quad$ Asset utilization ratio berpengaruh positif terhadap kinerja perusahaan.

$\mathrm{H}_{3 \mathrm{~b}}$ : Expense ratio berpengaruh negatif terhadap kinerja perusahaan.

\section{Kerangka Konseptual}

Berdasarkan teori dan penelitian terdahulu, maka dapat ditarik kerangka konseptual sebagai berikut:

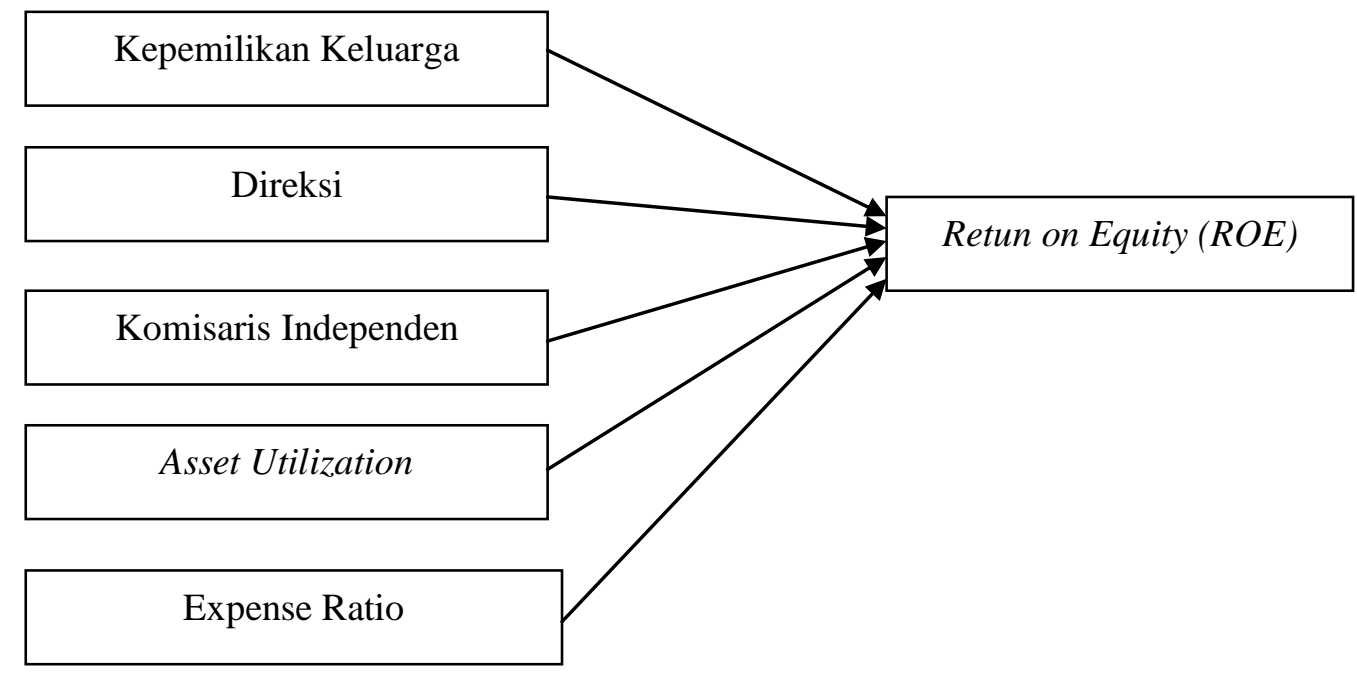

Gambar 1. Kerangka Konseptual

\section{METODE PENELITIAN \\ Sampel Penelitian}

Sampel yang digunakan adalah perusahaan yang terdaftar di Bursa Efek Indonesia periode 2016-2018. Data yang digunakan adalah data panel dengan jumlah observasi sebanyak 60 . 


\section{Defenisi Operasional Variabel}

Tabel 1. Defenisi Operasional Variabel Penelitian

\begin{tabular}{|l|l|}
\hline Variabel & Pengukuran \\
\hline Panel A: Variabel Dependen \\
\hline ROE & Laba bersih dibagi dengan total ekuitas \\
\hline Panel B: Variabel Independen & \multicolumn{2}{|l|}{} \\
\hline Kepemilikan Keluarga & $\begin{array}{l}\text { Jumlah saham yang dimiliki oleh keluarga dibagi dengan total } \\
\text { keseluruhan jumlah saham }\end{array}$ \\
\hline Direksi & Jumlah dewan direksi dalam perusahaan \\
\hline Komisaris Independen & Jumlah komisaris independen dibagi dengan total komisaris \\
\hline Asset Utilization & Jumlah penjualan dibagi dengan total aset \\
\hline Expense ratio & Jumlah beban operasi dibagi dengan jumlah penjualan \\
\hline
\end{tabular}

\section{Model Empiris}

Hipotesis yang telah dibentuk akan diuji dengan menggunakan model regresi linear. Pengujian tersebut akan dilakukan menggunakan model sebagai berikut:

$$
\underset{\varepsilon_{i, t}}{\mathrm{ROE}_{i, \mathrm{t}}}=\beta_{0}+\beta_{1} \mathrm{FAMOWN}_{\mathrm{i}, \mathrm{t}}+\beta_{2} \mathrm{DIR}_{\mathrm{i}, \mathrm{t}}+\beta_{3} \mathrm{KOMIN}_{\mathrm{i}, \mathrm{t}}+\beta_{4} \mathrm{AC1}_{\mathrm{i}, \mathrm{t}}+\beta_{5} \mathrm{AC} 2_{\mathrm{i}, \mathrm{t}}+
$$

\section{Keterangan :}

$\mathrm{ROE}_{\mathrm{i}, \mathrm{t}}$

:Kinerja perusahaan i pada periode t. yang diukur menggunakan proksi return on equity

Dalam penelitian ini proksi yang digunakan untuk Struktur Kepemilikan perusahaan adalah, sebagai berikut:

FAMOWN $\mathrm{i}_{\mathrm{i}, \mathrm{t}}$ :Struktur kepemilikan perusahaan i pada periode t. yang diukur menggunakan proksi kepemilikan keluarga

Dalam penelitian ini proksi yang digunakan untuk corporate governance perusahaan adalah, sebagai berikut:

$\mathrm{DIR}_{\mathrm{i}, \mathrm{t}} \quad$ :Corporate Governance perusahaan i pada periode t. yang diukur menggunakan proksi dewan direksi

KOMIN $_{\mathrm{i}, \mathrm{t}}$ :Corporate Governance perusahaan i pada periode t. yang diukur menggunakan proksi komisaris independen.

Dalam penelitian ini proksi yang digunakan untuk agency cost perusahaan adalah, sebagai berikut:

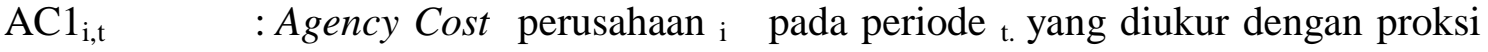
asset utilization

AC2 $2_{\mathrm{i}, \mathrm{t}} \quad$ : Agency Cost perusahaan i pada periode t. yang diukur dengan proksi expense ratio 


\section{HASIL PENELITIAN}

\section{Statistik Deskriptif}

Tabel 2. Statistik Deskriptif Variabel Penelitian

\begin{tabular}{|l|c|c|c|c|c|}
\hline Keterangan & Mean & Median & St.dev & Maksimum & Minimum \\
\hline ROE & 0,119918 & 0,119583 & 0,086010 & 0,303792 & 0,000448 \\
\hline Kepemilikan Keluarga & 0,699912 & 0,721216 & 0,164782 & 0,987639 & 0,333829 \\
\hline Direksi & 5,466667 & 5,000000 & 2,142916 & 11,00000 & 3,000000 \\
\hline Komisaris Independen & 0,430317 & 0,400000 & 0,105337 & 0,666667 & 0,250000 \\
\hline Asset Utilization & 0,872754 & 0,793976 & 0,764089 & 3,712541 & 0,081021 \\
\hline Expense Ratio & 0,365860 & 0,219754 & 0,307499 & 0,892119 & 0,027141 \\
\hline
\end{tabular}

Dari hasil pengumpulan data terhadap variabel-variabel penelitian diperoleh, ratarata kepemilikan keluarga 0,699912 , nilai rata-jumlah direksi 5,466667 , nilai rata-rata komisaris independen 0,430317 , nilai rata-rata asset utilization 0,872754 , dan nilai ratarata expense ratio 0,365860 .

\section{Uji Asumsi Klasik}

Berdasarkan hasil pengujian normalitas ditemukan bahwa data terdistrubusi secara normal, hal ini terlihat dari probability nya sebesar 0,329636 > alpha 0,05. Hasil pengujian multikolinearitas yang dilakukan, diperoleh ringkasan hasil bahwa masingmasing variabel independen memiliki koefisien korelasi dibawah 0,08. Dapat disimpulkan bahwa masing-masing variabel independen yang digunakan terbebas dari gejala multikolinieritas sehingga layak untuk pengujian tahap selanjutnya. Hasil pengujian heteroskedastisitas menunjukkan bahwa nilai observasi dari R-square $>0,05$, artinya terbebas dari masalah heteroskedastisitas. Hasil uji autokorelasi ditemukan nilai Durbin Watson sebesar 1,181567. Hal ini menunjukkan bahwa nilai DW terletak antara -2 dan 2, artinya terbebas dari masalah autokorelasi.

\section{Pengujian Hipotesis}

Uji statistik t dilakukan dengan cara uji pemilihan model yang terdiri dari common effect, fixed effect, dan random effect. Berdasarkan hasil uji model yang dilakukan diketahui hasil Chow Test yang membandingkan common effect dan fixed effect diperoleh nilai chi-square probability sebesar 0,0000 yang berarti chow test lebih memilih fixed effect sebagai model yang terbaik. Selanjutnya dilakukan uji hausman test untuk membandingkan antara fixed effect dan random effect, diperoleh nilai chi-square probability sebesar 0,0000 yang berarti hauman test lebih memilih fixed effect sebagai model yang terbaik.

Tabel 3. Hasil Pengujian Hipotesis

\begin{tabular}{|c|c|c|c|}
\hline Variabel & Coefficient & Probability & Keterangan \\
\hline $\begin{array}{l}\text { Kepemilikan } \\
\text { (FAMOWN) }\end{array}$ & $-0,016643$ & 0,8100 & Tidak Signifikan \\
\hline
\end{tabular}




\begin{tabular}{|l|c|c|c|}
\hline Direksi (Direksi) & 0,002773 & 0,5860 & Tidak signifikan \\
\hline $\begin{array}{l}\text { Komisaris Independen } \\
\text { (KOMIN) }\end{array}$ & 0,211476 & 0,0098 & Signifikan \\
\hline Asset Utilization (AC1) & 0,083880 & 0,0000 & Signifikan \\
\hline Expense Ratio (AC2) & $-0,056463$ & 0,0507 & Signifikan \\
\hline
\end{tabular}

\section{Pengaruh Struktur Kepemilikan terhadap Kinerja Keuangan}

Berdasarkan pada hasil pengujian hipotesis pertama diperoleh koeefisien regresi untuk variabel kepemilikan keluarga sebesar -0,016643 dengan probability 0,8100. Hasil ini menunjukkan bahwa nilai probability yaitu $0,8100>$ alpha 0,05 . Dari hasil ini dapat disimpulkan bahwa kepemilikan keluarga tidak berpengaruh terhadap kinerja keuangan.

Hasil penelitian ini sejalan dengan penelitian yang dilakukan oleh Chen et al (2005); Sitilonga dan Juniarti (2017). Namun, hasil penelitian ini tidak sejalan dengan penelitian yang dilakukan oleh Chu (2011); Astuti, dkk (2015); dan Indarwati (2015).

\section{Pengaruh Corporate Governance terhadap Kinerja Keuangan}

Berdasarkan pada hasil pengujian hipotesis 2 a diperoleh koeefisien regresi untuk variabel direksi sebesar 0,002773 dengan probability 0,5860. Hasil ini menunjukkan bahwa nilai probability yaitu $0,5860>$ alpha 0,05 . Dari hasil ini dapat disimpulkan bahwa jumlah direksi tidak berpengaruh terhadap kinerja keuangan. Hasil ini tidak sejalan dengan hasil penelitian yang dilakukan oleh Arora dan Sharma (2016), namun hasil ini sejalan dengan penelitian Buallay et al. (2017).

Selanjutnya untuk hipotesis $2_{\mathrm{b}}$ diperoleh koeefisien regresi untuk variabel komisaris independen sebesar 0,211476 dengan probability 0,0098. Hasil ini menunjukkan bahwa nilai probability yaitu $0,0098<$ alpha 0,05 . Dari hasil ini dapat disimpulkan bahwa komisaris independen berpengaruh terhadap kinerja keuangan.

Hasil ini sejalan dengan penelitian yang dilakukan oleh Baghat dan Bolton (2008); Darwis (2009); Prasinta (2012); dan Muchtar dan Darari (2013). Namun hasil penelitian ini tidak sejalan dengan penelitian yang dilakukan oleh Buallay et al. (2017). Hasil ini mengindikasikan bahwa adanya komisaris independen dalam perusahaan dapat memonitor jalnnya perusahaan sehingga dapat meningkat kinerja perusahaan.

\section{Pengaruh Agency Cost terhadap Kinerja Keuangan}

Berdasarkan pada hasil pengujian hipotesis $3_{\mathrm{a}}$ diperoleh koeefisien regresi untuk variabel kepemilikan keluarga sebesar 0,083880 dengan probability 0,0000. Hasil ini menunjukkan bahwa nilai probability yaitu $0,0000<$ alpha 0,05 . Dari hasil ini dapat disimpulkan bahwa jumlah asset utilization berpengaruh terhadap kinerja keuangan. Hasil penelitian ini sejalan dengan penelitian yang dilakukan oleh Layyinaturobaniyah, dkk (2014). Namun, hasil ini tidak sejalan dengan penelitian yang dilakukan oleh Fachrudin (2011).

Selanjutnya untuk hipotesis $3_{\mathrm{b}}$ diperoleh koeefisien regresi untuk variabel kepemilikan keluarga sebesar $-0,056463$ dengan probability 0,0507. Hasil ini menunjukkan bahwa nilai probability yaitu 0,0507 < alpha 0,05. Dari hasil ini dapat disimpulkan bahwa expense ratio berpengaruh terhadap kinerja keuangan. Hasil ini 
sejalan dengan penelitian yang dilakukan oleh Layyinaturobaniyah, dkk (2014). Namun, hasil ini bertolak belakang dengan penelitian yang dilakukan oleh Fachrudin (2011); Pandey dan Sahu (2019). Hasil ini mengindikasikan bahwa pemanfaatan biaya yang dikeluarkan mampu meningkatkan kinerja perusahaan yang diproksikan dengan ROE.

\section{E. KESIMPULAN}

Berdasarkan hasil penelitian dan pembahsan diatas, maka dapat disimpulkan bahwa:

1. Kepemilikan keluarga tidak berpengaruh terhadap Return on Equity (ROE) pada perusahaan keluarga yang terdaftar di Bursa Efek Indonesia periode 2016-2018.

2. Direksi tidak berpengaruh terhadap Return on Equity (ROE) pada perusahaan keluarga yang terdaftar di Bursa Efek Indonesia periode 2016-2018.

3. Komisaris Independen berpengaruh positif dan signifikan terhadap Return on Equity (ROE) pada perusahaan keluarga yang terdaftar di Bursa Efek Indonesia periode 2016-2018.

4. Asset utilization berpengaruh positif dan signifikan terhadap Return on Equity (ROE) pada perusahaan keluarga yang terdaftar di Bursa Efek Indonesia periode 2016-2018.

5. Expense ratio berpengaruh negatif dan signifikan terhadap Return on Equity (ROE) pada perusahaan keluarga yang terdaftar di Bursa Efek Indonesia periode 2016-2018.

\section{F. DAFTAR PUSTAKA}

Ang, J.S., R.A. Cole., J.W. Lin. 2000., Agency Costs and Ownership Structure. The Journal of Finance, Vol. 55, No.1, pp. 81-106.

Arora, Akshita., Sharma, Chandan. Corporate Governance and Firm Performance in Developing Countries. Corporate Governance, Vol.16. No.2, pp. 420-436.

Astuti, Apri Dwi., Rahman, Abdul., Sudarno. 2015. Pengaruh Kepemilikan Keluarga terhadap kinerja Perusahaan dengan Agency Cost sebagai Variabel Moderating. Jurnal Dinamika Akuntansi, Vol.7, No.2.

Baghat, S. D., Bolton, B., 2008. Corporate governance and Firm Performance. Journal of Corporate Finance 14.pp.257-273

Black,B.S.H.Jang.W.Kim., 2006. Predicting Firm's Corporate Governance Choices: Evidence from Korea. Journal of Corporate Finance, vol. 12:pp.660-691.

Brigham, Eugene F., Ehrhardt Michael C., 2011. Financial Management : Theory and Practice. South-Westrn Cengage Learning.

Brown,L.D., Caylor, M.L. 2004. Corporate Governance and Firm Performance, Georgia State University Working Paper

Buallay, Amina; Hamdan, Allam; Zureigat, Qasim. 2017. Corporate Governance and Firm Performance: Evidence from Saudi Arabia. Australasian Accounting, Business, and Financing, Vol. 11.

Chen, Zhilan., Cheuang, Yan-Leung., Stouraitis, Aris., Wong, Anita WS. 2005. Owneship concentration, and dividend policy in Hong Kong. Pasific-Basin Finance Journal 13(4), 431-449

Chu, Wenyi., 2011. Family ownership and firm performance; Influence of family management, family control, and firm size. Asia Pasific Jornal of Management 28(4), 833-851. 
Darwis, Herman. 2009. Corporate Governance terhadap Kinerja Perusahaan. Jurnal Keuangan dan Perbankan, Vol.13

Fachrudin, Khaira Amalia. 2013. Analisis Pengaruh Struktiur Modal, Ukuran Perusahaan, dan Agency Cost terhadap Kinerja Perusahaan. Jurnal Akuntansi dan keuangan, Vol.13, No.1.

Faleye, Olubumi., 2007. Classified Boards, Firm Value, and Managerial Entrenchment. Journal of Financial Economics. Hal.501-529.

Indarwati, Penta. 2015. Analisis Pengaruh Struktur Kepemilikan terhadap Kinerja Perusahaan Manufaktur. Jurnal Ilmu Manajemen dan Akuntansi Terapan, Vol.6.

Jensen, Michael., Meckling, William., 1976. Theory of the Firm: Managerial Behavior, Agency Cost, and Ownership Structure. Journal of Financial Economics 3: 305360.

Jensen, Michael C., 1986. Agency Cost of Free cash Flow,Corporate Finance, and Takeovers, American Economic Review 76 (2), 323-329.

Layyinaturrobaniyah., Sudarsono, Rachmat., Fitriyana, Desi. 2014. Agency Cost pada Perusahaan Keluarga dan Non Keluarga. Jurnal Siasat Bisnis, Vol.8, No.2.

Lukviarman, Niki., 2004. Etika Bisnis Tak Berjalan di Indonesia: Ada Apa Dalam Corporate Governance?. Jurnal Siasat Bisnis. No. 9 Vol. 2.

Muchtar, Susy., dan Darari, Elsa. 2013. Pengaruh Corporate Governance terhadap Kinerja Perusahaan Manufaktur yang Terdaftar di Bursa Efek Indonesia. Jurnal Manajemen dan Pemasaran Jasa, Vol. 5 dan 6.

Nam, S-W., I.C. Nam., 2004. Corporate Governance in Asia: recent evidence from Indonesia, Republic of Korea, Malaysia, and Thailand, Asian Development Bank Institute.

Pandey, Lrishna Dayal., Sahu, Tarak Nath. 2019. Debt Financing, Agency Cost, and Firm Performance: Evidence from India. SAGO Journal.

Porter, E Michael., 1991. Towards a dynamic theory of strategy. Strategic Management Journal. Vol. 12, Issue S2, pages 95-117.

Prasinta, Dian. 2012. Pengauh Good Corporate Governance terhadap Kinerja Keuangan. accounting Analysis Journal, Vol.1, No.2.

Rashid, Afzalur., 2015. Managerial Ownership and Agency Cost: Evidence from Bangladesh. Journal Business and Ethics.

Saltaji, Issam MF., 2013. Corporate Governance and Agency Cost, How to Control Agency Cost. Internal Auditing and Risk Management.

Shleifer, A., Vishny R.W., (a) 1986. Large Shareholders and Coporate Control. Journal of Political Economy, Vol. 94, No. 3, pp. 461-488.

Shleifer, Andrei., Vishny, Robert., (b) 1997. A Survey of Corporate Governance.The Journal of Finance. June, Vol. 52 No.2. 